\title{
Mentoring and Respiratory Care
}

Approximately 6 years ago, the American Association for Respiratory Care (AARC) established a task force to identify the evolving role of the respiratory therapist (RT). The members of this task force acknowledged the complexities of providing medical interventions along the continuum of care, and reported the knowledge and competencies required to provide safe and effective care was ever growing. ${ }^{1,2}$ This task force identified a need to plan for the transition of the RT from a bedside care provider to a professional who participates in the development of the care plan, executes that plan, and educates patients and families. In this issue of Respiratory CARE, Richards and colleagues confirm the findings of the AARC's task force by highlighting the numerous attributes required of clinicians to optimize care for patients with cystic fibrosis. ${ }^{3}$ In practice, the authors report, RTs must have an innate understanding of the pathophysiology of cystic fibrosis, familiarity with the evidence-based guidelines for care, ${ }^{4-6}$ an integral knowledge of the types and application of airway clearance techniques, ${ }^{7}$ and the ability to work collaboratively with patients and families to develop a plan of care that best meets the patient's need. To complement clinical knowledge and technical abilities, well developed interpersonal skills assist RTs with identifying adherence barriers to daily regimens and promoting strategies to effectively manage this disease process.

See the Original Study on Page 764

It is unlikely that respiratory therapy students receive the education and training necessary to care for patients with cystic fibrosis through accredited post-secondary education. Depending on the availability of a cystic fibrosis care center within a healthcare organization, orientation and job experience may not sufficiently prepare RTs to care for patients with this chronic disease. The Cystic Fibrosis Foundation, however, recognized the need for a formal training process and established a mentoring program to better equip RTs with tools necessary for effective disease management for cystic fibrosis patients. The authors describe in detail the process and outcomes for this specialized training program.

The concept of mentoring is not foreign to healthcare. Rather, mentoring has been used in healthcare to bridge the gap between the educational process and the real-world experience. It has been reported in the literature as an effective method for sustaining high research outputs in academic medicine, ${ }^{8}$ as well as an effective tool for physician and nurse recruitment and retention. ${ }^{9-11}$ Mentoring motivates the mentor and protégé by presenting a clear organizational vision and creating a rewarding work environment. ${ }^{12}$ Mentoring has been described as "the very life blood" 13 of the respiratory care profession. However, a dearth of literature exists reporting its use or outcomes in respiratory care. The paper "A Preliminary Evaluation of the Effectiveness of the Cystic Fibrosis Foundation Mentoring Program for Respiratory Care" describes components of the mentoring process, such as selecting and matching participants, developing mentoring goals, establishing key knowledge attributes, and evaluating program outcomes. The authors report, through anecdotal evidence, outcomes similar to those reported in the medical and nursing literature: high retention rate reported among apprentices, increased job satisfaction, engaged workforce, and communities of practice. ${ }^{3}$ Although this paper may be of particular interest to RTs providing care to patients with cystic fibrosis, it also provides value to those interested in developing a mentoring program. The process Richards and colleagues describe can be used to support RTs as they transition from novices to experienced professionals with well defined disease management skills, in any care setting.

Teresa A Volsko MHHS RRT FAARC Department of Respiratory Care Akron Children's Hospital Akron, Ohio

\section{REFERENCES}

1. Kacmarek RM, Durbin CG Jr, Barnes TA, Kageler WV, Walton JR, O'Neil EH. Creating a vision for respiratory care in 2015 and beyond. Respir Care 2009;54(3):375-389.

2. Barnes TA, Gale DD, Kacmarek RM, Kageler WV. Competencies needed by graduate respiratory therapists in 2015 and beyond. Respir Care 2010;55(5):601-616.

3. Richards KM, Lester MK, Chin MJ, Marshall BC. A preliminary evaluation of the effectiveness of the Cystic Fibrosis Foundation mentoring program for respiratory care. Respir Care 2013;58(5):764769.

4. Flume PA, O'Sullivan BP, Robinson KA, Goss CH, Mogayzel PJ Jr, Willey-Courand DB, et al. Cystic fibrosis pulmonary guidelines: 


\section{MENTORIng AND Respiratory CARE}

chronic medications for maintenance of lung health. Am J Respir Crit Care Med 2007;176(10):957-969.

5. Flume PA, Mogayzel PJ Jr, Robinson KA, Rosenblatt RL, Quittell L, Marshall BC, et al. Cystic fibrosis pulmonary guidelines: pulmonary complications: hemoptysis and pneumothorax. Am J Respir Crit Care Med 2010;182(3):298-306.

6. Flume PA, Mogayzel PJ Jr, Robinson KA, Goss CH, Rosenblatt RL, Kuhn RJ, et al. Cystic fibrosis pulmonary guidelines: treatment of pulmonary exacerbations. Am J Respir Crit Care Med 2009;180(9): 802-808.

The author has disclosed no conflicts of interest.

Correspondence: Teresa A Volsko MHHS RRT FAARC, Department of Respiratory Care, Akron Children's Hospital, One Perkin's Square, Akron OH 44308. E-mail: tvolsko@chmca.org.

DOI: $10.4187 /$ respcare. 02450
7. Flume PA, Robinson KA, O'Sullivan BP, Finder JD, Vender RL, Willey-Courand DB, et al. Cystic fibrosis pulmonary guidelines: airway clearance therapies. Respir Care 2009;54(4):522-537.

8. Santoro N, McGinn AP, Cohen HW, Kaskel F, Marantz PR, Mulvihill $\mathrm{M}$, Schoenbaum $\mathrm{E}$. In it for the long-term: defining the mentorprotégé relationship in a clinical research training program. Acad Med 2010;85(6):1067-1072.

9. Kohrs FP, Mainous AG 3rd. Retention of family medicine faculty development fellows in academic medicine. Fam Med 1999;31(1): 23-27.

10. Ramanan RA, Taylor WC, Davis RB, Phillips RS. Mentoring matters. Mentoring and career preparation in internal medicine residency training. J Gen Intern Med 2006;21(4):340-345.

11. Leners DW, Wilson VW, Connor P, Fenton J. Mentorship: increasing retention probabilities. J Nurs Manag 2006;14(8):652-654.

12. Nelsey L, Brownie S. Effective leadership, teamwork and mentoring: essential elements in promoting generational cohesion in the nursing workforce and retaining nurses. Collegian 2012;19(4):197202.

13. Chatburn RL. Advancing beyond the average: the importance of mentoring in professional achievement. Respir Care 2004;49(3):304308. 